\title{
Reception of Jesus as healer in Mark's community
}

\begin{tabular}{|c|c|}
\hline \multicolumn{2}{|c|}{$\begin{array}{l}\text { Author: } \\
\text { Zorodzai Dube }{ }^{1} \text { (D) }\end{array}$} \\
\hline \multicolumn{2}{|c|}{$\begin{array}{l}\text { Affiliation: } \\
{ }^{1} \text { Department of New } \\
\text { Testament Studies, Faculty of } \\
\text { Theology and Religion, } \\
\text { University of Pretoria, } \\
\text { South Africa }\end{array}$} \\
\hline \multicolumn{2}{|c|}{$\begin{array}{l}\text { Research Project Details: } \\
\text { Project Leader: Z. Dube } \\
\text { Project Number: } 13339746\end{array}$} \\
\hline \multicolumn{2}{|c|}{$\begin{array}{l}\text { Description: } \\
\text { This research is part of the } \\
\text { project, 'Healing during the } \\
\text { New Testament', directed by } \\
\text { Dr Dube, Department of New } \\
\text { Testament Studies, Faculty of } \\
\text { Theology and Religion, } \\
\text { University of Pretoria, } \\
\text { South Africa. }\end{array}$} \\
\hline \multicolumn{2}{|c|}{$\begin{array}{l}\text { Corresponding author: } \\
\text { Zoro Dube, } \\
\text { zoro.dube@up.ac.za }\end{array}$} \\
\hline \multicolumn{2}{|c|}{$\begin{array}{l}\text { Dates: } \\
\text { Received: } 28 \text { Feb. } 2018 \\
\text { Accepted: } 27 \text { June } 2018 \\
\text { Published: } 30 \text { July } 2018\end{array}$} \\
\hline \multicolumn{2}{|c|}{$\begin{array}{l}\text { How to cite this article: } \\
\text { Dube, Z., 2018, 'Reception of } \\
\text { Jesus as healer in Mark's } \\
\text { community', HTS Teologiese } \\
\text { Studies/Theological Studies } \\
74(1), 4952 . \text { https://doi. } \\
\text { org/10.4102/hts.v74i1.4952 }\end{array}$} \\
\hline \multicolumn{2}{|c|}{$\begin{array}{l}\text { Copyright: } \\
\text { (C) 2018. The Authors. } \\
\text { Licensee: AOSIS. This } \\
\text { is licensed under the } \\
\text { Creative Commons } \\
\text { Attribution License. }\end{array}$} \\
\hline \multicolumn{2}{|l|}{ Read online: } \\
\hline 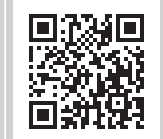 & $\begin{array}{l}\text { Scan this QR } \\
\text { code with your } \\
\text { smart phone or } \\
\text { mobile device } \\
\text { to read online. }\end{array}$ \\
\hline
\end{tabular}

This study traces the manner in which the evangelist Mark presents Jesus as a healer. While this is the primary focus, I am also interested, from an identity perspective, in why Mark is keen to present Jesus as the best physician. Healers during the 1st century were varied. Cities had professional healers with great knowledge of the Greek Hippocratic tradition. The entire empire had famous temples of Asclepius and Apollo. Common people had diverse knowledge about various illnesses with remedies varying from herbs to exorcisms. Amidst all this and located in southern Syria in the northern regions of Galilee, Mark presents Jesus as a healer. The study concludes that Mark presents Jesus as an efficient healer with great power and authority. Though Mark is mute regarding other healers such as Asclepius and Apollo, near whose temples patients would sleep for days waiting for healing, he wants to remind the adherents of Jesus' movement that they are following a great physician. A few selected stories from Mark's gospel illustrate this argument.

\section{Introduction}

The gospels are memory documents; they were told variably and orally to particular first communities -Matthew's gospel to an Antiochean community, Mark's to a Northern Galilean community, Luke's to an Antiochean community and John's to an Asian community. Being memory documents, their primary purpose is idiosyncratically presenting memories about Jesus. One such memory that stands out from Mark's gospel is that Jesus was a healer (Dube 2018a, 2018b:1). In this study, using various healing stories from Mark's gospel, I explore how Mark presents Jesus as a healer and what kind of healer he wants adherents to understand.

To understand how Jesus was remembered as a healer and to put his healing practices into context, we need to describe the worldview of Mark's gospel (Horsley 2001:12). Located in the southern part of Antioch or Northern Galilee, Mark's community was a rural subsistence community (Van Eck 1995:12). The gospel of Mark comes from a culture in which the spiritual infuses the ordinary - a reality that John Pilch calls 'personalistic worldview'. People with such a worldview interpret reality from the perspective of a spiritual worldview (Pilch 2000:65). Instead of looking for viruses and bacteria behind illness, a personalistic worldview focuses on why one allows the spiritual world to expose one to sickness. Daily events have a spiritual cause and the task of the individual is keeping in touch with voices from the spiritual world.

From an African perspective, this has an affinity with the African worldview (Mbiti 1990:61). Most Africans go through their daily lives questioning why events happen the way they do and how the spiritual manipulates the natural world. For example, if illness or other misfortune strikes, a personalistic worldview interprets this as disapproval from the spiritual world. Similarly, in Mark's gospel, when the disciples saw the fig tree that Jesus cursed, they interpreted its dry condition as evidence that the tree had been supernaturally cursed (Mk 11). Again in Mark 4:39, while almost drowning, Jesus woke up and rebuked the storm, indicating the spiritual force behind the raging storm.

With regard to people, Mark's audience lived communal lives. The individual found meaning in the rest of the household and community. With regards to sickness, people relied on social connectedness for meaning and support. Pilch calls this a 'collectivistic' or 'dyadic' existence (Pilch 2000:65). To illustrate, for healing all sick people were brought to Jesus by immediate family members. The paralytic man was brought to Jesus by relatives (Mk 2:1). The deaf man was also brought by relatives (Mk 7:32). Pilch also elaborates that within the household it was the responsibility of the father - head of the household - to make sure that all household members were in good health. If sickness happened, he was the first to diagnose the spiritual cause and find an appropriate remedy.

Connected to this, always in Mark's gospel, sickness has a gender aspect. To be sick is to be incapacitated from performing gender roles. For example, men are affected by unclean spirits, 
paralysis, deafness, blindness and withered hand, which 'are symbolic zones of Mediterranean human person' (Pilch 2000:66). Within subsistence societies, men provide for the family through hard work, usually located outside the domestic space. Therefore, if sickness causes paralysis, deafness or blindness, it incapacitates one's ability to perform his gender role as a man. Equally, sickness incapacitates women from performing their gender roles as women. Pilch explains, saying, 'women are afflicted with unclean spirits, fever, death and menstrual irregularities (haemorrhage)' (Pilch 2000:66). For example, the haemorrhaging woman is unable to perform her role of being a wife and having children (Mk 5:25). Equally, because of her sickness, Simon's motherin-law could not serve food, which she was only able to do after being healed (Mk 1:25).

\section{Jesus as a Sangoma or shaman model}

A model is a heuristic tool that helps to explain a phenomenon and, in my view, Jesus fits a Sangoma model. Throughout Mark's gospel Jesus did not perform surgery, a skill associated with the Hippocratic dogmatic healers. Equally, he did not perform external bodily observations of his patients before healing them, a skill that was associated with the Hippocratic Emperialists healers (Ferngren 2009). Instead, Jesus' healing involved exorcising the demonic forces causing sickness. Spiritual authority or power over evil spirits is an important aspect associated with his ability to heal (Pilch 2000:66).

Pieter Craffert proposes that Jesus was a shaman healer (Craffert 2008:12). A shaman healer functions in various social roles such as divination, exorcism, control of spirits, visions and spirit possession. Within Africa, a shaman is called a Sangoma (Dube 2018a:4). A Sangoma goes into a trance or state of possession, from which he taps into the spiritual world for insights regarding present circumstances. The most important aspect is that healing is performed by doing battle with the spiritual force causing the illness. On the part of the healer, certain requirements are needed. Foremost, the diviner must be possessed by a higher or bigger power that can command the evil spirit to manifest and leave its host.

In the gospel of Mark 3:24, the story regarding the accusations levelled against Jesus as being possessed by Beelzebub illustrates the point. In the story the accusers - the scribes had knowledge concerning possession and exorcism. Upon meeting Jesus they accused him of being possessed by Beelzebul, and 'by the prince of demons he casts out the demons' (v. 23). The accusation here indicates that a diviner healer must be possessed by a spirit for him or her to enter into metaphysical confrontation with demons. Jesus' response to the accusation reveals another aspect regarding divination. He says:

How can Satan cast out Satan? If a kingdom is divided against itself, that kingdom cannot stand. And if a house is divided against itself, that house will not be able to stand. And if Satan has risen up against himself and is divided, he cannot stand, but is coming to an end. (vv. 23-27)
The central aspect of Jesus' response is that spirits have different levels of power. A less powerful spirit cannot exorcise the more powerful one. Therefore, to perform exorcism, the exorcist must be possessed by a more powerful spirit. Thus, Jesus explains, saying that no one can enter a strong man's house and plunder his goods, unless he first binds the strong man (Moxnes 2003:134). In Mark 3:27, Jesus uses the word $\delta$ øn Jesus presents himself as one with more power over demons, able to subdue any kind of demonic forces, thus making people whole and able to resume their social roles. Selected stories further illustrate this point.

\section{Jesus - A powerful healer}

I begin with Mark's introduction (1:1). Mark begins his story

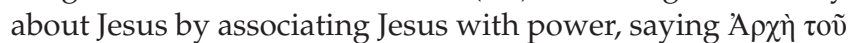

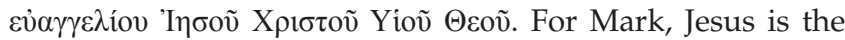
messiah and son of God - titles that present Jesus as divine. The title 'Messiah' was used to refer to a deliverer, while 'Son of God' was a title associated with individuals such as kings with supernatural power. Because rulers were believed to be possessed by the divine, their appearance and message was regarded as gospel - good news (Myers 1988:146). Robert Guelich comments that Mark, in addition to a reference to Jesus' death and resurrection during the early church, includes Jesus' earthly ministry (Guelich 2018). This means that the earthly appearance of Jesus to heal, teach and perform acts of mercy is the ultimate good news and not Augustus. The stage was set for spiritual confrontation against forces that deny wholeness and incapacitate people from fulfilling their social roles. How does Mark present Jesus as one who subdues, or one with power?

The healing of the demon-possessed man in the synagogue is purposely set to describe Jesus as having superior power, thus providing a yardstick to the rest of the healing stories that Mark remembered. The listeners are reminded that Jesus taught in the synagogue and that he is 'one with authority' - a confession that acts as prelude to what is about to happen. In terms of literary structure, the story forms an inclusion; it opens with a reference to Jesus teaching with authority (v. 23) and closes with the crowd being amazed at the authority of Jesus to cast out demons (v. 27). The victim of demon possession is a man and, given his condition, he was incapacitated from performing his gender roles as a man. Mark is careful to separate the man in the synagogue from the demon that spoke, making the confrontation a metaphysical battle. William Lane comments that the demon had usurped the man and was speaking through him (Lane 1974:73). In addition, being found in the synagogue, a public meeting place for men in the village, signifies the authority of the demon over the space. However, the demon's fortunes were about to change. From this moment onwards in the story, the attention shifts from the man to the conversation between the demon and Jesus. By moving the conversation into the cosmic realm, Mark heightens the intensity of the conflict.

The story follows the structure of common exorcism in antiquity - encounter (v. 23), defence (v. 23b), command 
(v. 25), exorcism (v. 25) and reaction from the crowd (v. 27) (Donahue \& Harrington 2002:82) (Guelich 2018:76). Upon seeing Jesus the demon taunts, saying, 'what have you to do with us, Jesus of Nazareth' (v. 24). In taunting Jesus, the demon is expressing its own power and intention to defend its territory (Myers 1988:146).

Illustratively, African Sangomas know that if an evil spirit taunts them it is an expression of defiance. In the process of taunting, the demon would give demands such as a request for animal sacrifice or any form of reparation. At this juncture, depending on his or her power, the exorcist should make a decision to either abort the process or proceed. If the manifesting demon is greater than the exorcist's power, then aborting the process is a wiser decision. At this moment, the victim may fall ill as a result of punishment by the demon for attempting to remove it. To proceed with the exorcism process without sufficient power may result in either the demon harming (even killing) both the host and the people around it. It is advisable that, before approaching a diviner, the patient or relatives should be absolutely sure that the healer is capable.

Alas, in the story, the taunting demon realised its vulnerability before Jesus and changed its aggression to supplication and bargaining, saying: 'Have you come to destroy us? I know who you are - the Holy One of God' (v. 24) (Guelich 2018:57; Myers 1988). It is puzzling why the demon is speaking in the plural. William Lane suggests that the demon is including the entire congregation in its speech, which may explain how the public space was controlled by the demon (Lane 1974:73). Robert Guelich comments that the naming of Jesus by the demon is an apotropaic device intended to manipulate Jesus by naming him (Guelich 2018:57). For Mark, the admission by the demon concerning the superior power of Jesus is the main theme in telling this story. William Lane comments that, while people address Jesus as teacher (9:17), Son of David (10:47), master (10:51) and Lord (7:8), on the other hand demons address Jesus as the Holy One of God (1:24), Son of God (3:11), son of the most high God (5:7) - expressions that indicate their knowledge of the power of Jesus (Lane 1974:73). John Donahue and Daniel Harrington's comment that the demon's address of Jesus as 'son of the most high God' is a Christological confession is problematic. Instead, like Guelich, I regard the confession of as admission of power and authority (Donahue \& Harrington 2002:85).

Demonstrating his power, Jesus commanded the demon, saying, 'Be silent, and come out of him!' And the unclean spirit, convulsing the man and crying out with a loud voice, came out of him. R.T France's statement that the silencing was intended to protect Jesus' messiahship is problematic. Instead it should be regarded an expression of authority (France 2002) The description is meant to heighten Jesus' authority. Two things: firstly, the call to silence is the climax of the exorcism narrative, which clearly demonstrates Jesus' ultimate power. Secondly, unlike other healers who relied on external power to perform healing, Jesus used his own power, which alludes to Mark's wish to have his listeners regard Jesus as divine, supernatural or a god (Lane 1974:73). Ched Myers explains, saying that exorcism is an apocalyptic combat myth, a confrontation in the war of myths in which Jesus asserts his alternative authority (Myers 1988:143). Exorcisms are a symbolic myth of confrontation between forces of oppression against Jesus' restoration power. On a symbolic level, plausibly, Jesus' exorcism is a restoration of the village of Capernaum and its men for them to perform their gender roles.

I argue that at an identity level, the exorcism in the synagogue answers the question, who is Jesus? For Mark, Jesus is the holy one or divine man who binds and plunders the house of the strongman (Mk 3:27) (Guelich 2018). Mark wants to tell the listeners that Jesus is not an ordinary healer; instead he is the ultimate healer and none are greater than him - a theme that he repeats in all of his healing stories. In my view, such a claim only makes sense if there were competing healers such as Asclepius and Apollo who rival Jesus' healing power. As such, Mark's healing stories are plausible as an identity marker, reminding the adherents of Jesus' healing household that their healer is the greatest physician. That Jesus is a powerful healer allows for the hearers to accord respect and flock to Jesus with all their sicknesses. A powerful healer attracts fame, which is what Mark communicates in the following healing episode.

\section{Jesus - An effective healer}

The second healing of Simon's mother-in-law happened on the same day as the exorcism in the synagogue, thus explaining that the house was not far from the synagogue. In addition, Mark wants the reader to connect the two stories by saying Jesus and the disciples left the synagogue and went to the house (vv. 29-31). Mark aims to connect the theme of the previous story with the healing of Simon's mother-in-law. Upon being told about the sickness, Jesus stood by the bedside and took the woman by the hand. Connected to the previous story, Jesus showed tremendous power and did not struggle in healing the sick or in casting away demons.

Here, that Simon's mother-in-law was instantly healed is the main point. Such quick and instant healing, in my view, is an indirect invitation to patients who had slept for days waiting for the visitation of the god at the temples of Asclepius. To emphasise the effectiveness of the healing, the woman resumed her gender role by serving the guests. Concerning this, Pilch explains that the presentation of sickness in the gospels is related to gender. In this case, because she was sick, the woman was unable to perform her gender role. Healing is a restoration of the self to society, enabling the person to resume normal societal duties. Importantly for Mark, Jesus' healing was not a gradual restoration of health; it was instant. Good healers are known for their effective healing methods.

An example from Zimbabwe may explain this point. Among the Shona people of Zimbabwe each village has various healers, but the most effective physician would receive 
patients from afar. In the region of Chipinge in Zimbabwe, famous healers welcome patients from as far away as $500 \mathrm{~km}$ who come from the capital city - Harare. Some family members go as far as asking the hospital authorities to remove their sick relatives from the hospital to consult a famous traditional healer. In connection to Mark, by instantly healing Peter's mother-in-law, Jesus is an effective physician, attracting patients from afar. R.T France says that because of his fame crowds were pulled to Jesus for healing (France 2002:117).

\section{Jesus - The famous physician}

To prove that Jesus was an effective healer with fame, Mark 1:32-39 narrates that Jesus' fame spread throughout the region of Nazareth. This section is characterised by statements such as 'many that were sick got healed', 'all', 'large numbers' and that the rumour of Jesus' healing power spread to the surrounding regions of Nazareth. Robert Guelich suggests that such narratives possibly functioned in early Christian missionary work as a marketing strategy concerning the power of Jesus (Guelich 2018:67). Mark uses hyperbolic language, giving the impression that the entire village came for healing and that many people sought after Jesus (Guelich 2018:67).

Why is Mark interested in the memory concerning Jesus' fame as healer? Plausibly, in the north in Syria, Mark is in proximity to the famous Temple of Apollo, known for its famous oracles. Similarly in Asia, Asclepius was known for various healing shrines (Avalos 1999:34; Ferngren 2009:50). Several extra-biblical writings make references regarding Jesus. The only plausible claim concerning Jesus' fame as a healer comes later in the 3rd century from Celsus, whose manuscript is referred to in Origen's rebuttal - namely Contra Celsum or 'against Celsus'. In this, Celsus had written, among others, claiming that Jesus had accumulated fame as a magician after studying in Egypt (Gallagher 1982:41). The context of this is that Celsus is writing opposing Jesus. However, in his opposition, he implicitly reveals one of the identities given to Jesus - that he was a famous magician. In my view, to claim that Jesus' fame as a healer spread throughout the region of Nazareth was putting him at the same level as famous healers such as Asclepius or Apollo.

\section{Jesus - The compassionate physician}

In Mark 1:43-44, the healing of the leper continues the theme that Jesus heals instantly. Concerning structure, the story has no location and does not flow well from the previous story. In my view the story closely imitates similar stories by Greek gods, such as Heracles, who appear from nowhere and serve people in need. In addition, the memory seeks to spread the news regarding the types of sickness that Jesus heals. The story's subtheme, seen from Jesus touching the man with leprosy, is that Jesus is a compassionate healer.

Leprosy was a contagious disease. Victims were quarantined outside the village, where they died or found their own healing. That the leper ran to Jesus suggests that Jesus was outside the village. This correlates with the reaction by the villagers, who, upon hearing that he had touched the man with leprosy, refused him entry (1:43-44). Seemingly, in the story, Mark struggles to silence the voices that accused Jesus of being ritually unclean and a carrier of infectious diseases (Dube 2018b:1). Mark seems to want to quiet this accusation with the claim that even lepers had heard the about the famous healer - Jesus. Not to miss the opportunity, the man with leprosy ran and touched Jesus, requesting his healing. At this point the teaching regarding ritual cleanliness was violated, which explains the refusal to have Jesus enter the village (vv. 43-44). However, Mark is interested in telling the instant healing of the leper.

In my view, by making Jesus suddenly appear and heal the leper, Mark is seemingly equating Jesus to gods like Heracles. Mark is making a claim that Jesus is a healer god in the same category as Heracles. Only gods such as Heracles were known to suddenly appear and rescue people in their time of need. Concerning Heracles, the poet Aristides writes, saying:

... we hear he does marvellous deeds at Gadira and is believed to be second to none of all gods. And on the other hand, in Messene in Sicily he frees men from all diseases and those who escape danger from the sea attribute the benefaction equally to Poseidon and Heracles. One could list many other places sacred to the god, and other manifestation of his power. (Cotter 1999:13)

The language of rescue from leprosy is equally evident in Mark's story concerning the leper. In addition, the motif of compassion, which is associated with Heracles, is clearly evident. To show that the leper is truly restored, Jesus pronounced, 'I will, be clean'. However, by instructing the leper to show himself to the priest, Jesus showed awareness of the Leviticus code regarding leprosy or any skin disease. The priest would further examine the skin and then instruct the victim to go to Jerusalem to offer sacrifices. William Lane suggests that the section regarding reporting to the priest may have been a later addition, meant to smooth the awkwardness regarding uncleanliness associated with the story (Lane 1974:88).

\section{Conclusion}

How does Mark want his audience to remember Jesus as a healer? In this study, Mark is not random in his reporting of Jesus as healer. For him, Jesus is the son of God - he is divine, a god. People during Jesus' time understood that any person with supernatural power was an embodiment of the god. Upon building this claim, Mark goes further to illustrate through various healing stories the nature of healer Jesus was. For Mark, Jesus is a powerful healer - his power supersedes that of all healers. He is the only one who can bind all forms of demonic forces. Jesus' power is evident through his authority over demonic forces such as the one controlling the synagogue, a public space. Further, Jesus heals instantly, which is evident in the healing of Simon's mother-in-law. Consequently, Jesus is a famous healer who heals all types of sickness. As such, outcasts such as the 
leper ran to him for instant healing. He is a vulnerable healer with great compassion for the sick, such as the leper. In giving this compelling evidence, in my view, Mark seeks to retain the allegiance of his audience - those who had given themselves to follow the Markan Jesus. These followers had to know that they were following the greatest physician of them all - Jesus.

\section{Acknowledgements Competing interests}

The author declares that he has no financial or personal relationships which may have inappropriately influenced him in writing this article.

\section{References}

Avalos, H., 1999, Health care and the rise of Christianity, Hendrickson, Pearbody, MA. Cotter, W., 1999, Miracles in Greco-Roman antiquity: A sourcebook, Routledge, London.

Craffert, P.F., 2008, The life of a Galilean shaman: Jesus of Nazareth in anthropologicalhistorical perspective, Wipf and Stock Publishers, Oregon.
Donahue, J.R. \& Harrington, D.J., 2002, The gospel of Mark, Liturgical Press, Collegeville, Minneapolis.

Dube, Z., 2018a, 'Models and perspectives concerning the identity of Jesus as healer' HTS Teologiese Studies/Theological Studies 74(1), 4925. https://doi.org/10.4102/ hts.v74i1.4925

Dube, Z., 2018b, 'The Talmud, the Hippocratic Corpus and Mark's healing Jesus on infectious diseases,' HTS (forthcoming).

Ferngren, G.B., 2009, Medicine \& health care in early Christianity, Johns Hopkins University Press Baltimore, Baltimore, MD.

France, R.T., 2002, The Gospel of mark: A commentary on the Greek text, Paternoster Press, Grand Rapids, MI.

Gallagher, E.V., 1982, Divine man or magician?: Celsus and Origen on Jesus, Scholars Press, Eugene.

Guelich, R.A., 2018, Mark 1-8: 26, Volume 34A, Zondervan, Dallas.

Horsley, R.A., 2001, Hearing the whole story: The politics of plot in Mark's gospel, Westminster John Knox Press, Louisville.

Lane, W.L., 1974, The gospel of Mark, Wm. B. Eerdmans Publishing, Grand Rapids, MI. Mbiti, J.S., 1990, African religions \& philosophy, Heinemann, Nairobi, Kenya.

Moxnes, H., 2003, Putting Jesus in his place: A radical vision of household and kingdom, Westminster John Knox Press, Louisville.

Myers, C., 1988, Binding the strong man: A political reading of Mark's story of Jesus, Orbis Books, Oregon.

Pilch, J.J., 2000, Healing in the new testament: Insights from medical and Mediterranean anthropology, Fortress Press, Minneapolis.

Van Eck, E., 1995, Galilee and Jerusalem in Mark's story of Jesus: A narratological and social scientific reading, Periodicle Section of the Nederduitsch Hervormde Kerk van Afrika, Pretoria, South Africa. 